\title{
Endoperoxide Derivatives from Marine Organisms: 1,2-Dioxanes of the Plakortin Family as Novel Antimalarial Agents
}

\author{
Caterina Fattorusso, ${ }^{\dagger, \|}$ Giuseppe Campiani, ${ }^{\dagger, \| l}$ Bruno Catalanotti, ${ }^{\dagger, \|}$ Marco Persico, ${ }^{\dagger, \| l}$ Nicoletta Basilico, ${ }^{\S, \|}$ Silvia Parapini, ${ }^{\S, \|}$ \\ Donatella Taramelli, ${ }^{\S}, \|$ Claudio Campagnuolo, ${ }^{\dagger, \|}$ Ernesto Fattorusso, ${ }^{\dagger, \|}$ Adriana Romano, ${ }^{\dagger, \|}$ and Orazio Taglialatela-Scafati ${ }^{*}, \dagger, \|$ \\ Dipartimento di Chimica delle Sostanze Naturali, Università di Napoli “Federico II", Via D. Montesano 49, 80131 Napoli, Italy, Dipartimento \\ Farmaco Chimico Tecnologico, Via Aldo Moro, Università di Siena, 53100 Siena, Italy, Dipartimento di Sanità Pubblica, Microbiologia, \\ Virologia, Università di Milano, Via Pascal 36, 20133 Milano, Italy, and European Research Centre for Drug Discovery and Development, \\ Banchi di Sotto 55, 53100 Siena Italy
}

Received July 28, 2006

Plakortin (1) is a remarkably simple 1,2-dioxane derivative, extracted from the marine sponge Plakortis simplex, showing a submicromolar activity against chloroquine-resistant strains of Plasmodium falciparum. Using plakortin as a novel antimalarial hit, we have prepared a series of semisynthetic derivatives in order to gain insights into the structural requirements of simple 1,2-dioxanes for exhibiting antimalarial activity. Their synthesis, spectroscopic and computational analysis, and in vitro antimalarial activity are herein reported. Results obtained, besides confirming the crucial role of the cycloperoxide functionality, revealed other structural features critical for antimalarial activity, namely the "Western" alkyl side chain, the dioxane ring conformation, and the absolute configuration of the stereogenic carbons on the 1,2-dioxane ring, when affecting the bioactive ring conformation.

\section{Introduction}

Malaria, a parasitic disease caused by protozoans belonging to the genus Plasmodium, is recognized as one of the most dramatic public health concerns of our days. Indeed, it occurs in over 90 countries worldwide and, according to valuations provided by the World Health Organization, 300 to 500 million clinical cases of malaria occur and 1.5-2 million people (most of them young children living in sub-Saharan Africa) are killed each year. ${ }^{1}$ The difficulties associated with the preparation of an effective vaccine against malaria can be ascribed to the complexity of this disease, that varies widely in epidemiology (variability in the species of malaria parasite that occur in a given area) and clinical manifestations in different parts of the world. However, the development and spread of drug-resistant strains of malaria parasites is probably the key factor in the resurgence of malaria emergency, also in areas where the disease had been eradicated, and is one of the greatest challenges to malaria control today. ${ }^{2}$ Unfortunately, the rate at which resistance is growing outpaces the development of new antimalarials and, thus, the number of effective drugs available to treat resistant malaria remains small.

Artemisinin, a cycloperoxide-containing sesquiterpene lactone extracted from the plant Artemisia annua, shows higher activity against chloroquine-resistant strains (CQ-R) than chloroquinesensitive strains (CQ-S) of P. falciparum. Accordingly, a series of artemisinin semisynthetic derivatives (artesunate, artemether, arteether), with improved pharmacokinetic properties, have been proposed for the treatment of severe malaria and, in some areas of South-East Asia, their combination with mefloquine offer the only reliable treatment for multidrug-resistant malaria. ${ }^{3}$ However, also in the case of artemisinin-derived molecules some problems are appearing. These are mostly related to (i) some

* To whom correspondence should be addressed. Phone: +39-081678509. Fax: +39-081-678552. E-mail: scatagli@unina.it.

†niversità di Napoli.

$\doteqdot$ Università di Siena.

$\S$ Università di Milano.

"European Research Centre for Drug Discovery and Development.

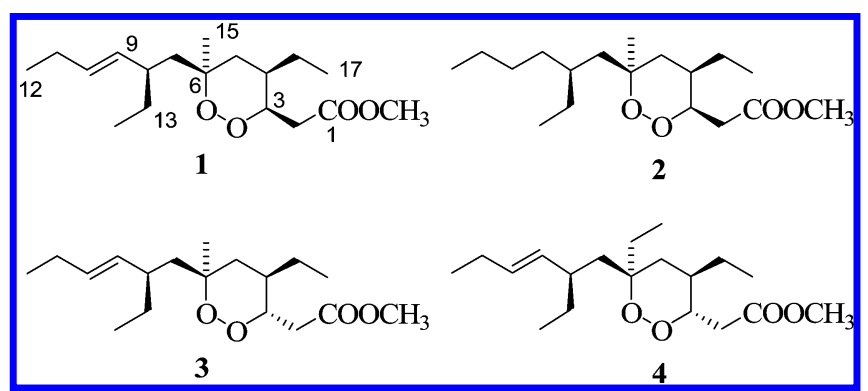

Figure 1. 1,2-Dioxane derivatives isolated from the sponge Plakortis simplex.

adverse effects (neurological and embriological) caused by their use, ${ }^{4}$ (ii) the costs associated with the extraction of artemisinin from natural sources and the complexity of alternative chemical syntheses. ${ }^{5}$

For these reasons, there is an urgent need for the rapid development of effective, safe, and synthetically affordable antimalarial agents. In this regard, we have been focusing our interest on 1,2-dioxane derivatives isolated from the Caribbean sponge Plakortis simplex possessing remarkably simple skeletons: the parent compounds of this class, plakortin (1) and its 9,10-dihydro analogue 2 , have been demonstrated to possess in vitro antimalarial activity in the submicromolar range, being particularly active on CQ-R strains $\left(\mathrm{IC}_{50}=0.41 \mu \mathrm{M}\right)$, and devoid of general cytotoxicity. ${ }^{6,7}$ More recently, we have isolated two additional analogues of plakortin from the same sponge, namely 3-epiplakortin (3) and plakortide Q (4) (Figure 1). ${ }^{8}$ These analogues showed in vitro antimalarial activity similar to that of plakortin $\left(\mathrm{IC}_{50}=0.51 \mu \mathrm{M}\right)$, suggesting that the activity of this class of compounds is not strictly dependent on a definite configuration of the stereogenic carbons belonging to the 1,2dioxane ring. Due to the tremendous need to develop new classes of affordable, rapidly acting drugs to treat uncomplicated malaria, exploiting the natural compound plakortin (1) as a novel antimalarial hit, we herein report the synthesis, the spectroscopic and computational analysis, and the in vitro antimalarial activity of a series of plakortin semisynthetic derivatives. 
Scheme 1. Reactions at the Oxygenated Carbons of Plakortin (1) Yielding Compounds 5-8

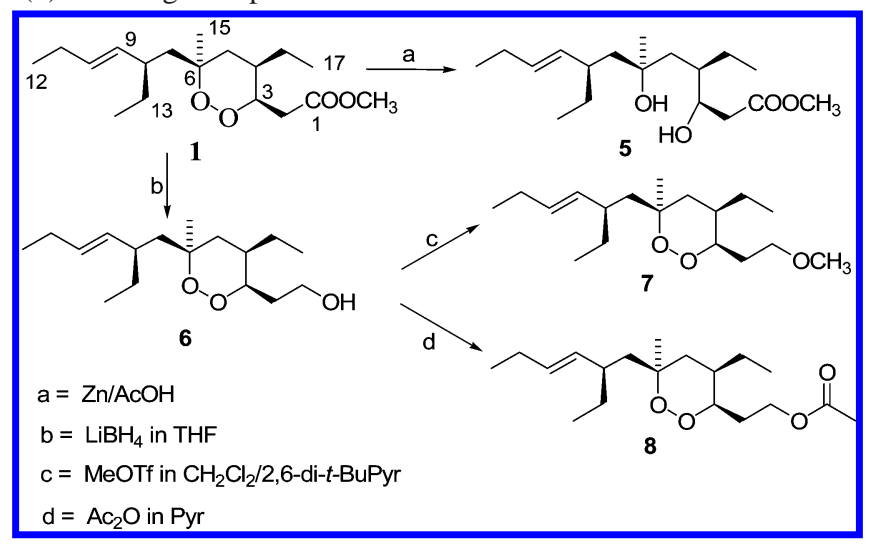

Chemistry. Plakortin (1) can be isolated in high amounts (more than $5 \%$ of the organic extract) from Plakortis simplex, following a very simple procedure, and it is stable under extraction and chromatographic purification steps. ${ }^{6}$ The availability of reasonable amounts of $\mathbf{1}$, its stability, and the presence in its monocyclic skeleton of functional groups that could be modified, appeared a good opportunity to investigate the effect of chemical transformations on antimalarial activity, allowing an extension of the structure-activity relationships (SARs) for this class of antimalarial endoperoxides.

The simple structure of plakortin offers three points for chemical interconversion: (i) the cycloperoxide bond, (ii) the carbon-carbon double bond, (iii) the ester group. These functionalities have been subjected to simple chemical reactions and the products obtained $(\mathbf{5}-\mathbf{1 2})$ have been fully characterized by means of MS and 1D and 2D NMR spectroscopy (data are listed in the Experimental Section).

A selective reduction of the cycloperoxide bond was accomplished upon treatment of plakortin (1) with acetic acid and $\mathrm{Zn}$ dust in dry ether, affording the diol $\mathbf{5}$ in good yield (Scheme 1). As for the ester group, its selective reduction, without affecting the cycloperoxide bond, was carried out by treating 1 with $\mathrm{LiBH}_{4}$ in dry THF, thus obtaining the primary alcohol derivative 6. The methylation of this group (compound 7) was performed upon treatment with methyl triflate in the presence of an excess of 2,6-di-tert-butylpyridine, while its acetylation, performed under standard conditions (acetic anhydride, pyridine), yielded compound $\mathbf{8}$ in quantitative amounts (Scheme 1).

Finally, we turned out our attention to reactions of the carbon-carbon double bond (Scheme 2). Its oxidative cleavage $\left(\mathrm{KMnO}_{4} / \mathrm{NaIO}_{4}\right.$ in $t$-BuOH/Na$\left./ \mathrm{CO}_{3}\right)$ afforded the carboxylic acid derivative $\mathbf{9}$ in high yield (80\%). A portion of compound 9 was subsequently methylated with diazomethane, obtaining a quantitative conversion into compound 10. The double bond of plakortin (1) was also epoxidized with meta-chloro-perbenzoic acid in dry $\mathrm{CH}_{2} \mathrm{Cl}_{2}$ and, as expected, this reaction afforded two different epoxides, $\mathbf{1 1}$ and 12, deriving from the syn approach of the reagent from both sides of the trans double bond. The trans geometry of the epoxide ring was unambiguously demonstrated for both $\mathbf{1 1}$ and $\mathbf{1 2}$ through the 2D ROESY spectrum: cross-peaks corresponding to the spatial coupling of $\mathrm{H}-9$ with $\mathrm{H}_{2}-11$ were detected in both cases (11: $\delta 2.44$ with $\delta 1.58 ; 12: \delta 2.52$ with $\delta 1.55)$. Given the unsuitability of X-ray structure determination, due to the oily nature of the compounds, determination of the correct absolute configuration at the epoxide carbons of $\mathbf{1 1}$ and $\mathbf{1 2}$ required a different strategy. In particular, a reaction that opened the epoxide ring and left (preferably)
Scheme 2. Reactions at the Carbon-Carbon Double Bond of Plakortin (1) Yielding Compounds 9-12 and Strategy for Determination of Absolute Configuration at the Epoxide Carbons of $\mathbf{1 1}$ and $\mathbf{1 2}$

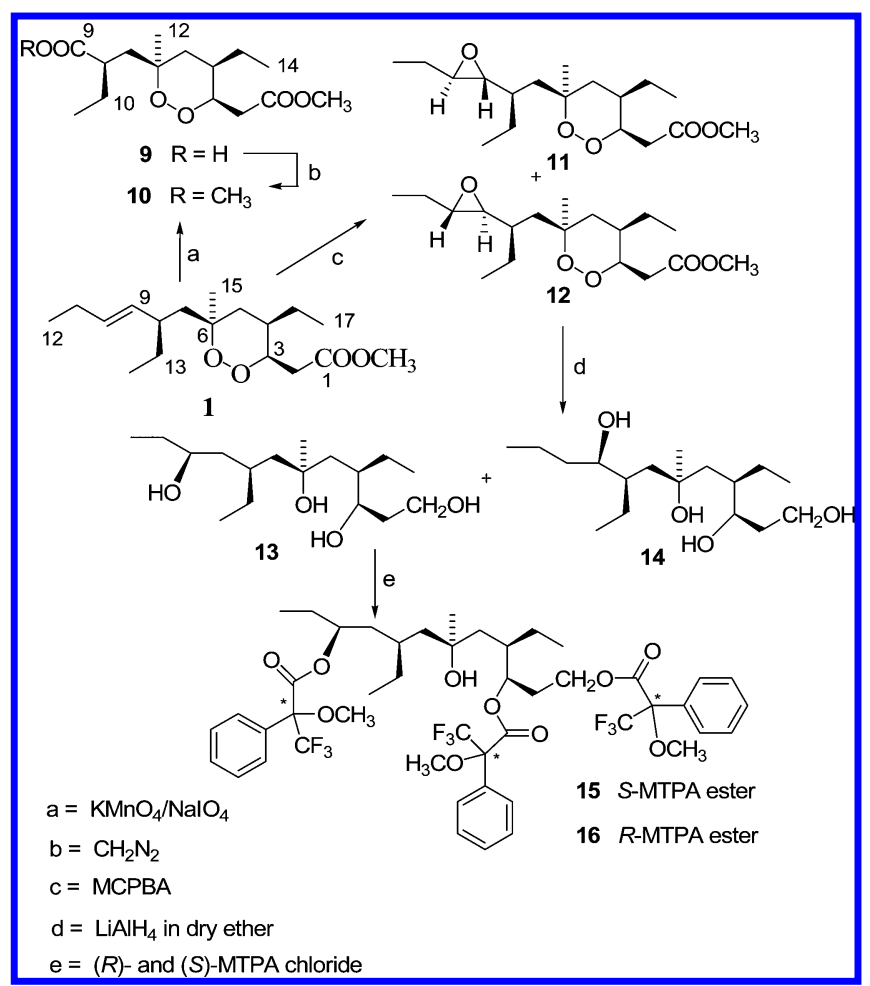

one secondary alcohol group, to be subjected to the Mosher methodology, appeared appropriate. To this end, we first attempted an application of the recently reported mild epoxide ring opening by reaction with methanol, catalyzed by copper(II) tetrafluoroborate, ${ }^{9}$ but, unfortunately, a complex mixture of products, apparently coming from concomitant reactions of the cycloperoxide bond, was obtained. Thus, we decided to turn to the complete reduction of one of the two epoxides (12), by using $\mathrm{LiAlH}_{4}$ in dry ether. In this way, only two tetraol derivatives, 13 and 14, were obtained, and inspection of their NMR spectra confirmed that they actually were two regioisomers differing for the position of only one hydroxyl group (at C-10 and at C-9, respectively). Compound $\mathbf{1 3}$ was then esterified by using an excess of $(R)$ - and $(S)$-MTPA chloride in dry pyridine, thus obtaining the MTPA triester derivatives $\mathbf{1 5}$ and 16, respectively. These were analyzed following the modified Mosher method, ${ }^{10}$ and the $S$ configuration was thus assigned at C-10 of $\mathbf{1 3}$. Consequently, the $S$ configuration could be assigned at C-10 of $\mathbf{1 2}$ and, given the trans geometry of the epoxide ring in 12, its absolute configuration was determined as $9 S, 10 S$. On account of the enantiomeric relationship existing between the epoxide carbons of $\mathbf{1 1}$ and 12, we assigned the absolute configuration of the corresponding chiral carbons in $\mathbf{1 1}$ as $9 R, 10 R$.

\section{Results and Discussion}

The new semisynthetic plakortin derivatives 5-12 were tested for their in vitro antimalarial activity, using the pLDH assay, against D10 (chloroquine sensitive, CQ-S) and W2 (chloroquine resistant, CQ-R) strains of $P$. falciparum. Results are reported in Table 1.

First, it is noteworthy the complete inefficacy of diol 5, demonstrating that, as reported for artemisinins, the cycloperoxide functionality plays a crucial role in the antimalarial activity of plakortin derivatives. Second, all the new semi- 
Table 1. In Vitro Antimalarial Activity of Plakortin (1) and of Semisynthetic Derivatives 6-12 against D10 (CQ-S) and W2 (CQ-R) Strains of Plasmodium falciparum $^{a}$

\begin{tabular}{|c|c|c|c|c|}
\hline & $\mathbf{R}_{\mathbf{1}}$ & $\mathbf{R}_{\mathbf{2}}$ & $\begin{array}{c}\text { D10 } \\
I_{50} \text { in } \mu \mathrm{M} \\
\end{array}$ & $\begin{array}{c}\text { W2 } \\
\text { IC }{ }_{50} \text { in } \mu \mathrm{M}\end{array}$ \\
\hline 1 & & & $0.87 \pm 0.22$ & $0.41 \pm 0.13$ \\
\hline 6 & $\widehat{n} \widehat{c}$ & & $0.83 \pm 0.12$ & $0.48 \pm 0.11$ \\
\hline 7 & & & $0.74 \pm 0.25$ & $0.41 \pm 0.10$ \\
\hline 8 & & & $0.84 \pm 0.20$ & $0.46 \pm 0.12$ \\
\hline 9 & & & $1.20 \pm 0.20$ & $1.23 \pm 0.12$ \\
\hline 10 & & & $0.85 \pm 0.18$ & $0.78 \pm 0.13$ \\
\hline 11 & & & $1.05 \pm 0.13$ & $0.50 \pm 0.15$ \\
\hline 12 & & & $1.20 \pm 0.13$ & $0.70 \pm 0.10$ \\
\hline $\begin{array}{l}\text { Chloroquine } \\
\text { Artemisinin }\end{array}$ & & & $\begin{array}{c}0.05 \pm 0.02 \\
0.013 \pm 0.004\end{array}$ & $\begin{array}{c}0.81 \pm 0.31 \\
0.009 \pm 0.005\end{array}$ \\
\hline
\end{tabular}

${ }^{a}$ Data are means \pm SD of four different experiments in triplicate. Compound 5 (in which the cycloperoxide function is replaced by the 3,6diol function) proved to be completely inactive $\left(\mathrm{IC}_{50}>20 \mu \mathrm{M}\right)$ against both strains.

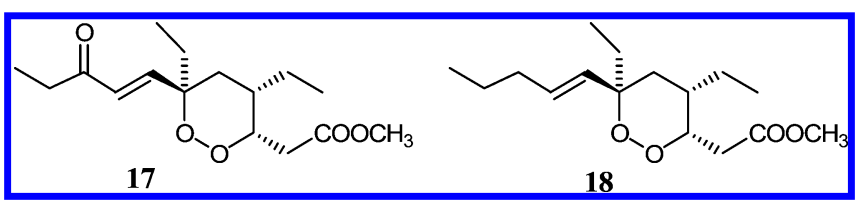

Figure 2. Plakortin-related molecules isolated from other sponges.

synthetic compounds are more active on W2 (CQ-R strains) than on D10 (CQ-S strains), with the exception of 9 which presents similar activity on both strains. Going into detail, some interesting considerations can be made: (i) the substitution of the ester function (1) with different groups such as hydroxy (6), methoxy (7), and acetoxy (8) does not affect activity and selectivity for the tested strains of Plasmodium falciparum; moreover, these compounds present a collinearity between the activity variation on D10 (CQ-S strains) and W2 (CQ-R strains); (ii) changes on the "Western" alkyl side chain appear to have a more significant effect on the antimalarial activity, differently affecting activity against CQ-S and CQ-R strains. The decreased activity of compound 9 against both $P$. falciparum strains suggests unfavorable parasite penetration properties due to the presence of the free carboxylic function. Accordingly, the esterification of the carboxylic group (10) determines a slight overall improvement in the antimalarial activity. On the other hand, compounds $\mathbf{1 1}$ and $\mathbf{1 2}$ show an activity similar to that of $\mathbf{9}$ on CQ-S strains, while they exhibit a 2-fold increase of activity against CQ-R strains. Interestingly, some data available in the literature for plakortin-related molecules appear to strengthen the observation that changes on the "Western" alkyl side chain can significantly influence the antimalarial activity. Compounds 17 and 18 (Figure 2), which are close analogues of plakortin (1), are much less active than $1 .^{11}$ In particular, compound $\mathbf{1 7}$ shows a reduced activity ( $\mathrm{IC}_{50} 1.9 \mu \mathrm{M}$ ) on W2 (CQ-R strain), while compound 18, differing only for the absence of the ketone group, is practically inactive $\left(\mathrm{IC}_{50}>10 \mu \mathrm{M}\right)$ on $\mathrm{W} 2 .{ }^{11}$

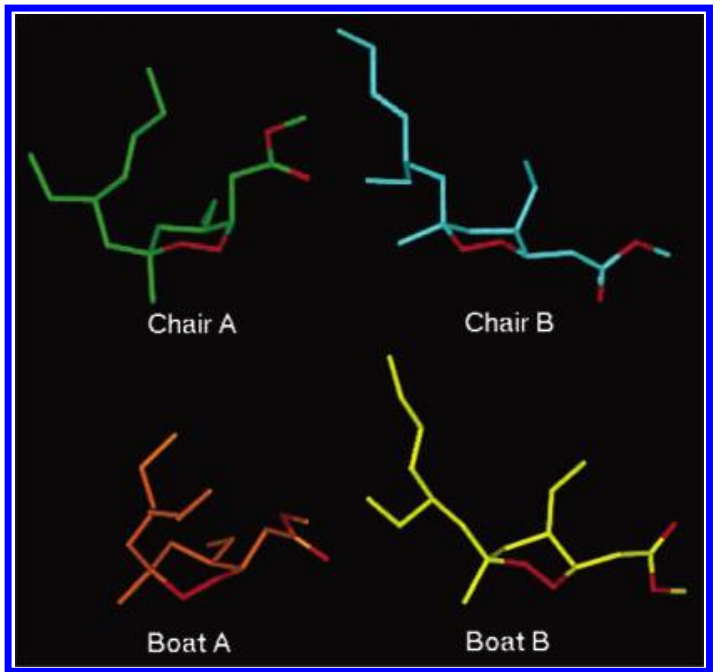

Figure 3. Lowest energy minima of each 1,2-dioxane ring conformation family of plakortin. Carbons are in green (chair A), cyan (chair $\mathrm{B}$ ), orange (boat A), and yellow (boat B); oxygens are in red. All hydrogens are omitted for clarity. Parallel families were also found for the other 1,2-dioxanes investigated.

In order to investigate the role played by the conformational parameters on the antimalarial activity of plakortin-related endoperoxides, we performed a full computational analysis on the new derivatives $\mathbf{6}-\mathbf{1 2}$ as well as on the reference compounds $\mathbf{1}-\mathbf{4}^{6-8}$ and on the plakortin-related compounds $\mathbf{1 7}$ and $\mathbf{1 8} .^{11}$ The resulting conformers can been grouped into four families (Figure 3) in relation to the dioxane ring conformations, named chair A, chair B, boat A, and boat B (Table 2), demonstrating a strong preference for the chair conformations, in agreement with the previously observed conformational behavior of the 1,2 dioxane ring system. ${ }^{12}$ It can be noted that all the molecules exhibiting a good antimalarial activity (i.e., $\mathrm{IC}_{50}<1 \mu \mathrm{M}$ on CQ-R strains, 1-4, 6-12) present the same conformational preference of the dioxane ring (Chair A, Table 2). It is noteworthy that, while the epimerization at C-3 (3 and 4) does not affect the conformation of the dioxane ring, the change in the conformational behavior (Table 2) of compounds $\mathbf{1 7}$ and 18 can be attributed to the concomitant epimerization at C-4, which changes the relative orientation of the ethyl chain with respect to the "Western" alkyl side chain (Figure S1, Supporting Information). The importance of the endoperoxide ring conformation is strengthened by comparison with the structure of artemisinin. Indeed, the most favorite conformation (Chair A) of the dioxane ring of plakortin (1) and its active derivatives overlaps well with the peroxide ring-constrained conformation of artemisinin (Figure 4). On the other hand, the complete lack of activity of compound $\mathbf{1 8}$ with respect to $\mathbf{1 7}$ confirms that small changes in the "Western" alkyl side chain of plakortinrelated structures can markedly influence the antimalarial activity, even if the molecules show the same conformation of the dioxane ring.

\section{Conclusions}

The mechanism of action of plakortin as well as that of related simple endoperoxides is still a matter of debate. However, the present study, besides confirming the crucial role of the cycloperoxide functionality, took into consideration other structural features critical for antimalarial activity: (i) the "Western" alkyl side chain, (ii) the dioxane ring conformation, (iii) the absolute configuration of the sterogenic carbons on the 1,2-dioxane ring, only when affecting the bioactive dioxane ring conformation. This latter observation, together with the com- 
Table 2. Conformational Preference of 1,2-Dioxane Ring for Reference Compounds 1-4, New Semisynthetic Derivatives 6-12, and Plakortin-Related Compounds $\mathbf{1 7}$ and $\mathbf{1 8}$

\begin{tabular}{|c|c|c|c|}
\hline compd & $\begin{array}{l}\text { 1,2-dioxane ring } \\
\text { conformation }\end{array}$ & $\begin{array}{l}\% \text { of conformers } \\
\text { within } 5 \mathrm{kcal} / \mathrm{mol} \\
\text { from } \mathrm{GM}^{a}\end{array}$ & $\begin{array}{c}\Delta E \text { from the } \mathrm{GM}^{a} \\
\text { of the lowest energy } \\
\text { conformer }(\mathrm{kcal} / \mathrm{mol})\end{array}$ \\
\hline \multirow[t]{4}{*}{1} & chair A & 92 & 0.00 \\
\hline & chair B & 7 & 3.56 \\
\hline & boat A & 1 & 4.62 \\
\hline & boat B & - & $>5$ \\
\hline \multirow[t]{4}{*}{2} & chair A & 82 & 0.00 \\
\hline & chair B & 14 & 2.09 \\
\hline & boat A & 4 & 4.40 \\
\hline & boat B & - & $>5$ \\
\hline \multirow[t]{4}{*}{3} & chair A & 95 & 0.00 \\
\hline & chair B & 2.5 & 4.59 \\
\hline & boat A & 2.5 & 4.07 \\
\hline & boat B & - & $>5$ \\
\hline \multirow[t]{4}{*}{4} & chair A & 98 & 0.00 \\
\hline & chair B & - & $>5$ \\
\hline & boat A & 2 & 4.49 \\
\hline & boat B & - & $>5$ \\
\hline \multirow[t]{4}{*}{6} & chair A & 93 & 0.00 \\
\hline & chair B & 7 & 4.39 \\
\hline & boat A & - & $>5$ \\
\hline & boat B & - & $>5$ \\
\hline \multirow[t]{4}{*}{7} & chair A & 86 & 0.00 \\
\hline & chair B & 14 & 3.03 \\
\hline & boat A & - & $>5$ \\
\hline & boat B & - & $>5$ \\
\hline \multirow[t]{4}{*}{8} & chair A & 90 & 0.00 \\
\hline & chair B & 10 & 3.53 \\
\hline & boat A & - & $>5$ \\
\hline & boat B & - & $>5$ \\
\hline \multirow[t]{4}{*}{9} & chair A & 77 & 0.00 \\
\hline & chair B & 18 & 2.27 \\
\hline & boat A & 5 & 4.41 \\
\hline & boat B & - & $>5$ \\
\hline \multirow[t]{4}{*}{10} & chair A & 97 & 0.00 \\
\hline & chair B & 3 & 4.93 \\
\hline & boat A & - & $>5$ \\
\hline & boat B & - & $>5$ \\
\hline \multirow[t]{4}{*}{11} & chair A & 79 & 0.00 \\
\hline & chair B & 21 & 3.61 \\
\hline & boat A & - & $>5$ \\
\hline & boat B & - & $>5$ \\
\hline \multirow[t]{4}{*}{12} & chair A & 84 & 0.00 \\
\hline & chair B & 16 & 3.07 \\
\hline & boat A & - & $>5$ \\
\hline & boat B & - & $>5$ \\
\hline \multirow[t]{4}{*}{17} & chair A & 15 & 2.73 \\
\hline & chair B & 78 & 0.00 \\
\hline & boat A & - & $>5$ \\
\hline & boat B & 7 & 4.64 \\
\hline \multirow[t]{4}{*}{18} & chair A & 30 & 2.41 \\
\hline & chair B & 64 & 0.00 \\
\hline & boat A & - & $>5$ \\
\hline & boat B & 6 & 4.82 \\
\hline
\end{tabular}

${ }^{a}$ Global minimum energy conformer.

parable activity of the diastereomers $\mathbf{1 1}$ and $\mathbf{1 2}$, suggests the absence of a stereospecific interaction with the putative antimalarial molecular target. A thorough investigation on the mechanism of action of plakortins, which is ongoing in our laboratories, could better clarify the role of the "Western" side chain and of the dioxane ring conformation in modulating the activity of these simplified cycloperoxide scaffolds, providing further valuable information to optimize the antimalarial profile of novel, synthetically affordable, endoperoxides of the plakortin series.

\section{Experimental Section}

General Methods. Optical rotations $\left(\mathrm{CHCl}_{3}\right)$ have been measured on a Perkin-Elmer 192 polarimeter equipped with a sodium lamp $(\lambda=589 \mathrm{~nm})$ and a 10-cm microcell. Low-resolution ESIMS

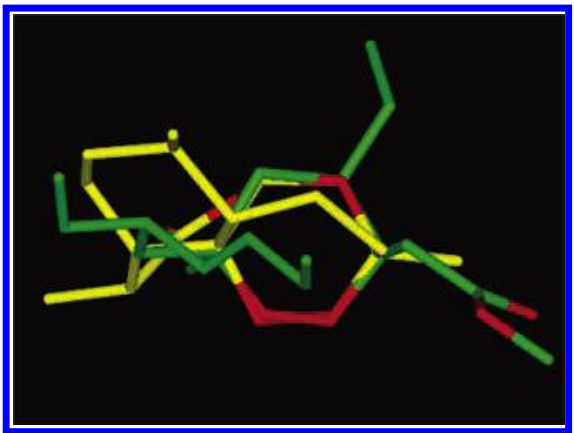

Figure 4. Superimposition of the lowest energy conformer of plakortin (1) on artemisinin X-ray structure (CSDS code: QNGHSU). Carbons are in green for plakortin (1) and in yellow for artemisinin; oxygens are in red. All hydrogens are omitted for clarity.

(positive ions) experiments were performed on an Applied Biosystem API 2000 triple quadrupole mass spectrometer. The spectra were recorded by infusion into the ESI source using $\mathrm{MeOH}$ as the solvent. Low- and high-resolution EI mass spectra $(70 \mathrm{eV}$, direct inlet) were performed on a VG Prospec (FISONS) mass spectrometer. ${ }^{1} \mathrm{H}(500 \mathrm{MHz})$ and ${ }^{13} \mathrm{C}(125 \mathrm{MHz})$ NMR spectra were determined on a Varian UnityInova 500 NMR spectrometer; chemical shifts are referenced to the residual solvent signal $\left(\mathrm{CDCl}_{3}: \delta_{\mathrm{H}}=7.26, \delta_{\mathrm{C}}=77.0\right)$. Homonuclear ${ }^{1} \mathrm{H}$ connectivities were determined by COSY experiments. Through-space ${ }^{1} \mathrm{H}$ connectivities were demonstrated using a 2D ROESY experiments with a mixing time of $500 \mathrm{~ms}$. One bond heteronuclear ${ }^{1} \mathrm{H}-{ }^{13} \mathrm{C}$ connectivities were determined with the HSQC experiment. Two and three bond ${ }^{1} \mathrm{H}-{ }^{13} \mathrm{C}$ connectivities were determined by HMBC experiments optimized for a ${ }^{3} J_{\mathrm{CH}}$ of $8.0 \mathrm{~Hz}$. Medium-pressure liquid chromatography (MPLC) was performed using a Büchi 861 apparatus using Merck SI60 (230-400 mesh) stationary phase. High performance liquid chromatography (HPLC) separations in isocratic mode were achieved on a Beckmann apparatus equipped with refractive index detector and with Phenomenex LUNA SI60 (250 $\times 4 \mathrm{~mm}$ ) columns.

Animal Material, Extraction, and Isolation. A specimen of Plakortis simplex was collected in July 2002 along the coasts of Bahamas. A voucher specimen is deposited at the Dipartimento di Chimica delle Sostanze Naturali, Italy with the ref no. 02-10. The organism was immediately frozen after collection and kept frozen until extraction, when the sponge (43 g, dry weight after extraction) was homogenized and extracted with methanol $(4 \times 500 \mathrm{~mL})$ and with chloroform $(4 \times 500 \mathrm{~mL})$. The methanol extract was initially partitioned between $\mathrm{H}_{2} \mathrm{O}$ and $n-\mathrm{BuOH}$, and then the organic phase was combined with the $\mathrm{CHCl}_{3}$ extract and concentrated in vacuo to afford a brown oil $(22.1 \mathrm{~g})$. This was subjected to chromatography on a column packed with RP18 silica gel and eluted with $\mathrm{H}_{2} \mathrm{O} / \mathrm{MeOH}$ 9:1 $\left(\mathrm{A}_{1}\right), \mathrm{H}_{2} \mathrm{O} / \mathrm{MeOH}$ 7:3 $\left(\mathrm{A}_{2}\right), \mathrm{H}_{2} \mathrm{O} / \mathrm{MeOH}$ 4:6 $\left(\mathrm{A}_{3}\right)$, $\mathrm{H}_{2} \mathrm{O} / \mathrm{MeOH}$ 2:8 $\left(\mathrm{A}_{4}\right)$, and $\mathrm{MeOH}\left(\mathrm{A}_{5}\right)$. Fractions $\mathrm{A}_{4}$ and $\mathrm{A}_{5}$ were combined $(6.5 \mathrm{~g})$ and further chromatographed by MPLC $\left(\mathrm{SiO}_{2}\right.$ 230-400 mesh; solvent gradient system of increasing polarity from $n$-hexane to $\mathrm{MeOH})$. MPLC fractions eluted with $n$-hexane/EtOAc 9:1 were rechromatographed over $\mathrm{SiO}_{2}$ column, using a solvent gradient system from $n$-hexane to $n$-hexane/EtOAc $8: 2$, to afford plakortin $(\mathbf{1}, 1.18 \mathrm{~g})$.

Reduction of Plakortin Cycloperoxide Bond. Plakortin (1, 35 $\mathrm{mg}, 0.11 \mathrm{mmol}$ ) in $200 \mu \mathrm{L}$ of dry ether was treated with $200 \mu \mathrm{L}$ of acetic acid and an excess $(80 \mathrm{mg})$ of $\mathrm{Zn}$ dust and then stirred vigorously for $24 \mathrm{~h}$ at room temperature. After confirmation of disappearance of the starting material by TLC, the solution was neutralized with $\mathrm{Na}_{2} \mathrm{CO}_{3}$ and the solid removed by filtration. The solvent was then evaporated, and the obtained product was partitioned between $\mathrm{H}_{2} \mathrm{O}$ and $\mathrm{CHCl}_{3}$. The organic phase contained compound 5 (29 mg, $0.092 \mathrm{mmol}$, yield $83.4 \%$ ), in a pure state.

Compound 5: Colorless oil. $[\alpha]_{\mathrm{D}}^{25}-5\left(c=0.10\right.$ in $\left.\mathrm{CHCl}_{3}\right)$. ESMS: $m / z 315[\mathrm{M}+\mathrm{H}]^{+}, 337[\mathrm{M}+\mathrm{Na}]^{+}$. EIMS: $m / z, 296(\mathrm{M}$ - 18), $281(\mathrm{M}-33)$. HREIMS: $m / z$ 314.2467, calcd for $\mathrm{C}_{18} \mathrm{H}_{34} \mathrm{O}_{4}$ $\mathrm{m} / \mathrm{z}$ 314.2457. ${ }^{1} \mathrm{H}$ NMR $\left(\mathrm{CDCl}_{3}\right): \delta 5.53(\mathrm{H}-10, \mathrm{dt}, J=15.2,6.2$ 
$\mathrm{Hz}) ; 5.21(\mathrm{H}-9$, dd, $J=15.2,9.0 \mathrm{~Hz}) ; 4.16(\mathrm{H}-3, \mathrm{dt}, J=10.4,2.1$ $\mathrm{Hz}) ; 3.70\left(\mathrm{H}_{3}-18, \mathrm{~s}\right) ; 2.46(\mathrm{H}-2 \mathrm{a}, \mathrm{dd}, J=15.9,10.4 \mathrm{~Hz}) ; 2.34(\mathrm{H}-$ 2b, dd, $J=15.9,2.1 \mathrm{~Hz}) ; 2.13(\mathrm{H}-8, \mathrm{~m}) ; 2.03\left(\mathrm{H}_{2}-11, \mathrm{q}, J=6.2\right.$ $\mathrm{Hz}) ; 1.91(\mathrm{H}-4, \mathrm{~m}) ; 1.67$ (H-5a, dd, $J=13.5,9.8 \mathrm{~Hz}) ; 1.55(\mathrm{H}-7 \mathrm{a}$, overlapped); 1.53 (H-7b, overlapped); 1.38 (H-13a, m); 1.35 (H$5 \mathrm{~b}$, overlapped); 1.27 (H-16a, m); 1.21 (H-13b, m); $1.17\left(\mathrm{H}_{3}-15\right.$, s); $1.13(\mathrm{H}-16 \mathrm{~b}, \mathrm{~m}) ; 0.98\left(\mathrm{H}_{3}-12, \mathrm{t}, J=6.2 \mathrm{~Hz}\right) ; 0.92\left(\mathrm{H}_{3}-17, \mathrm{t}, J\right.$ $=7.3 \mathrm{~Hz}) ; 0.84\left(\mathrm{H}_{3}-14, \mathrm{t}, J=6.3 \mathrm{~Hz}\right) \cdot{ }^{13} \mathrm{C} \mathrm{NMR}\left(\mathrm{CDCl}_{3}\right): \delta$ 173.7 (C-1); 134.8 (C-9); 133.8 (C-10); 73.0 (C-6); 70.6 (C-3); $51.7\left(\mathrm{OCH}_{3}\right) ; 49.7$ (C-7); $40.8(\mathrm{C}-8) ; 40.7$ (C-5); 40.5 (C-4); 36.6 (C-2); 29.7 (C-13); 26.8 (C-15); 26.4 (C-16); 25.6 (C-11); 13.7 (C-12); 12.3 (C-17); 11.5 (C-14).

Reduction of the Ester Group of Plakortin. Plakortin (1, 100 $\mathrm{mg}, 0.32 \mathrm{mmol}$ ) was dissolved in $3.0 \mathrm{~mL}$ of dry THF under argon flow at $0{ }^{\circ} \mathrm{C}$, and then $450 \mu \mathrm{L}$ of a $2 \mathrm{M}$ solution of $\mathrm{LiBH}_{4}$ in $\mathrm{THF}$ $(0.9 \mathrm{mmol})$ and $30 \mu \mathrm{L}$ of dry $\mathrm{MeOH}$ were added dropwise to the solution. The reaction was kept under stirring for $2 \mathrm{~h}$ at $0{ }^{\circ} \mathrm{C}$. Then, $30 \mu \mathrm{L}$ of $1 \mathrm{M}$ aqueous $\mathrm{NaOH}$ was added to the obtained mixture, which was partitioned between water and $\mathrm{CHCl}_{3}$. The organic phase, dried with $\mathrm{Na}_{2} \mathrm{SO}_{4}$ and concentrated in vacuo, was purified by HPLC (LUNA SI60 $250 \times 4$ eluent $n$-hexane/EtOAc 75:25) affording pure compound 6 (78 $\mathrm{mg}, 0.28 \mathrm{mmol}, 87.5 \%$ yield).

Compound 6: Colorless oil. $[\alpha]_{\mathrm{D}}{ }^{25}+55\left(c=0.10\right.$ in $\left.\mathrm{CHCl}_{3}\right)$. ESMS: $m / z 285[\mathrm{M}+\mathrm{H}]^{+}, 307[\mathrm{M}+\mathrm{Na}]^{+}$. EIMS: $m / z, 284(\mathrm{M})$, $266(\mathrm{M}-18)$. HREIMS: $\mathrm{m} / \mathrm{z} 284.2339$, calcd for $\mathrm{C}_{17} \mathrm{H}_{32} \mathrm{O}_{3} \mathrm{~m} / \mathrm{z}$ 284.2351. ${ }^{1} \mathrm{H}$ NMR $\left(\mathrm{CDCl}_{3}\right): \delta 5.36(\mathrm{H}-10, \mathrm{dt}, J=16.3,6.6 \mathrm{~Hz})$; 5.09 (H-9, dd, $J=16.3,9.5 \mathrm{~Hz}) ; 4.08(\mathrm{H}-3, \mathrm{~m}) ; 3.81\left(\mathrm{H}_{2}-1, \mathrm{t}, J=\right.$ $6.0 \mathrm{~Hz}) ; 2.16$ (H-2a, overlapped); 2.08 (H-4, overlapped); $2.03(\mathrm{H}-$ 8, overlapped); $1.99\left(\mathrm{H}_{2}-11, \mathrm{q}, J=6.6 \mathrm{~Hz}\right) ; 1.49$ (H-2b, ddd, $J=$ 13.8, 6.0, $4.3 \mathrm{~Hz}) ; 1.44$ (H-7a, overlapped); 1.40 (H-5a, overlapped); $1.37\left(\mathrm{H}_{3}-15, \mathrm{~s}\right) ; 1.36$ (H-16a, overlapped); 1.32 (H-5b, overlapped); 1.27 (H-13a, m); 1.23 (H-7b, overlapped); 1.15 (H-16b, overlapped); 1.15 (H-13b, overlapped); $0.95\left(\mathrm{H}_{3}-12, \mathrm{t}, J=6.3 \mathrm{~Hz}\right) ; 0.87\left(\mathrm{H}_{3^{-}}\right.$ $14, \mathrm{t}, J=6.6 \mathrm{~Hz}) ; 0.79\left(\mathrm{H}_{3}-17, \mathrm{t}, J=6.6 \mathrm{~Hz}\right) .{ }^{13} \mathrm{C} \mathrm{NMR}\left(\mathrm{CDCl}_{3}\right)$ : $\delta 134.3$ (C-9); 132.0 (C-10); 81.5 (C-6); 80.5 (C-3); 60.5 (C-1); 46.4 (C-7); 39.9 (C-8); 34.7 (C-4); 34.3 (C-5); 29.9 (C-16); 29.2 (C-13); 26.8 (C-2); 25.2 (C-11); 21.0 (C-15); 13.7 (C-12); 11.1 (C-17); 11.0 (C-14).

Methylation of Compound 6. Compound 6 (25 mg, 0.088 mmol) was dissolved in dry $\mathrm{CH}_{2} \mathrm{Cl}_{2}(3 \mathrm{~mL})$ at $0{ }^{\circ} \mathrm{C}$, and an excess of 2,6-di-tert-butylpyridine $(130 \mu \mathrm{L})$ and $50 \mu \mathrm{L}(0.44 \mathrm{mmol})$ of methyl trifluoromethansolfonate was added dropwise to the solution. The reaction mixture was left under stirring overnight and then treated with saturated $\mathrm{NaHCO}_{3}$. The organic phase, dried with $\mathrm{Na}_{2} \mathrm{SO}_{4}$ and concentrated in vacuo, was purified by HPLC (LUNA SI60 $250 \times 4$ eluent $n$-hexane/EtOAc 85:15) affording pure compound 7 (20 mg, $0.067 \mathrm{mmol}, 76.1 \%$ yield).

Compound 7: Colorless oil. $[\alpha]_{\mathrm{D}}{ }^{25}+75\left(c=0.10\right.$ in $\left.\mathrm{CHCl}_{3}\right)$. ESMS: $m / z 299[\mathrm{M}+\mathrm{H}]^{+}, 321[\mathrm{M}+\mathrm{Na}]^{+}$. EIMS: $m / z 298(\mathrm{M})$, 266 (M - 32). HREIMS: $\mathrm{m} / \mathrm{z}$ 298.2500, calcd for $\mathrm{C}_{18} \mathrm{H}_{34} \mathrm{O}_{3} \mathrm{~m} / \mathrm{z}$ 298.2509. ${ }^{1} \mathrm{H}$ NMR $\left(\mathrm{CDCl}_{3}\right): \delta 5.36(\mathrm{H}-10, \mathrm{dt}, J=16.3,6.6 \mathrm{~Hz})$; 5.10 (H-9, dd, $J=16.3,9.5 \mathrm{~Hz}) ; 4.06(\mathrm{H}-3, \mathrm{~m}) ; 3.53\left(\mathrm{H}_{2}-1, \mathrm{~m}\right)$; $3.34\left(\mathrm{OCH}_{3}, \mathrm{~s}\right) 2.16$ (H-2a, overlapped); 2.12 (H-2b, overlapped); 2.09 (H-4, overlapped); 2.03 (H-8, overlapped); $1.99\left(\mathrm{H}_{2}-11, \mathrm{q}, J\right.$ $=6.6 \mathrm{~Hz}) ; 1.50(\mathrm{H}-7 \mathrm{a}$, overlapped $) ; 1.43(\mathrm{H}-5 \mathrm{a}, \mathrm{dd}, J=13.8,4.3$ $\mathrm{Hz}) ; 1.37\left(\mathrm{H}_{3}-15, \mathrm{~s}\right) ; 1.36(\mathrm{H}-16 \mathrm{a}$, overlapped); $1.32(\mathrm{H}-7 \mathrm{~b}$, overlapped); 1.27 (H-13a, m); 1.24 (H-5b, dd, $J=13.8,6.9 \mathrm{~Hz}$; 1.15 (H-13b, overlapped); 1.14 (H-16b, overlapped); $0.96\left(\mathrm{H}_{3}-12\right.$, $\mathrm{t}, J=6.6 \mathrm{~Hz}) ; 0.87\left(\mathrm{H}_{3}-14, \mathrm{t}, J=6.6 \mathrm{~Hz}\right) ; 0.80\left(\mathrm{H}_{3}-17, \mathrm{t}, J=6.6\right.$ Hz). ${ }^{13} \mathrm{C} \mathrm{NMR}\left(\mathrm{CDCl}_{3}\right): \delta 134.3(\mathrm{C}-9) ; 131.4(\mathrm{C}-10) ; 81.1$ (C-6); 79.0 (C-3); 69.4 (C-1); $58.8\left(\mathrm{OCH}_{3}\right) ; 46.5$ (C-7); 40.1 (C-8); 34.8 (C-4); 34.7 (C-5); 29.8 (C-13); 29.6 (C-16); 25.5 (C-2); 25.0 (C11); 21.4 (C-15); 13.8 (C-12); 11.3 (C-14); 11.1 (C-17).

Acetylation of Compound 6. Compound $6(20 \mathrm{mg}, 0.070 \mathrm{mmol})$ was dissolved in dry pyridine $(1 \mathrm{~mL})$ and treated with $\mathrm{Ac}_{2} \mathrm{O}(1$ $\mathrm{mL}$ ). After standing overnight, the reaction was worked up by addition of a few drops methanol to destroy the excess $\mathrm{Ac}_{2} \mathrm{O}$, water (ca. $5 \mathrm{~mL}$ ), and EtOAc (ca. $15 \mathrm{~mL}$ ). The organic phase was washed sequentially with $2 \mathrm{~N} \mathrm{H}_{2} \mathrm{SO}_{4}$, saturated $\mathrm{NaHCO}_{3}$, and brine. After drying $\left(\mathrm{Na}_{2} \mathrm{SO}_{4}\right)$ and removal of the solvent, $22.0 \mathrm{mg}(0.069 \mathrm{mmol})$ of compound $\mathbf{8}$ was obtained.
Compound 8: Colorless oil. $[\alpha]_{\mathrm{D}}{ }^{25}+47\left(c=0.10\right.$ in $\left.\mathrm{CHCl}_{3}\right)$. ESMS: $m / z 327[\mathrm{M}+\mathrm{H}]^{+}, 350[\mathrm{M}+\mathrm{Na}]^{+}$. EIMS: $m / z, 326(\mathrm{M})$, $266\left(\mathrm{M}-\mathrm{CH}_{3} \mathrm{COOH}\right)$. HREIMS: $\mathrm{m} / \mathrm{z}$ 326.2466, calcd for $\mathrm{C}_{19} \mathrm{H}_{34} \mathrm{O}_{4} \mathrm{~m} / \mathrm{z}$ 326.2457. ${ }^{1} \mathrm{H}$ NMR $\left(\mathrm{CDCl}_{3}\right): \delta 5.36(\mathrm{H}-10, \mathrm{dt}, J=$ $16.3,6.6 \mathrm{~Hz}) ; 5.09$ (H-9, dd, $J=16.3,9.6 \mathrm{~Hz}) ; 4.27$ (H-1a, m); $4.21(\mathrm{H}-1 \mathrm{~b}, \mathrm{~m}) ; 4.04(\mathrm{H}-3, \mathrm{~m}) ; 2.23(\mathrm{H}-2 \mathrm{a}, \mathrm{m}) ; 2.10(\mathrm{H}-4$, overlapped); 2.03 (H-8, overlapped); $2.03\left(\mathrm{OCOCH}_{3}, \mathrm{~s}\right) ; 1.99\left(\mathrm{H}_{2-}\right.$ $11, \mathrm{q}, J=6.6 \mathrm{~Hz}) ; 1.59(\mathrm{H}-2 \mathrm{~b}$, overlapped $) ; 1.41(\mathrm{H}-7 \mathrm{a}$, overlapped); 1.37 ( $\left.\mathrm{H}_{3}-15, \mathrm{~s}\right) ; 1.36$ (H-16a, overlapped); 1.34 (H5a, overlapped); 1.29 (H-5b, overlapped); 1.26 (H-13a, overlapped); 1.15 (H-7b, overlapped); 1.15 (H-16b, overlapped); 1.13 (H-13b, overlapped); $0.96\left(\mathrm{H}_{3}-12, \mathrm{t}, J=6.6 \mathrm{~Hz}\right) ; 0.88\left(\mathrm{H}_{3}-14, \mathrm{t}, J=6.6\right.$ $\mathrm{Hz}) ; 0.80\left(\mathrm{H}_{3}-17, \mathrm{t}, J=6.6 \mathrm{~Hz}\right) \cdot{ }^{13} \mathrm{C}$ NMR $\left(\mathrm{CDCl}_{3}\right): \delta 171.1$ $\left(\mathrm{CH}_{3} \mathrm{CO}\right) ; 134.2$ (C-9); 131.3 (C-10); 81.2 (C-6); 78.6 (C-3); 61.7 (C-1); 46.5 (C-7); 40.1 (C-8); 34.8 (C-4); 34.5 (C-5); 30.3 (C-16); 29.8 (C-13); 25.4 (C-11); 23.9 (C-2); $21.5\left(\mathrm{CH}_{3} \mathrm{CO}\right) ; 21.1$ (C-15); 14.0 (C-12); 11.4 (C-14); 11.0 (C-17).

Oxidative Cleavage of Plakortin. To a solution of plakortin (120 mg, $0.385 \mathrm{mmol}$ ) in $40 \mathrm{~mL}$ of $t-\mathrm{BuOH}$ were added $26 \mathrm{~mL}$ of $0.04 \mathrm{M} \mathrm{Na}_{2} \mathrm{CO}_{3}$ and $150 \mathrm{~mL}$ of an aqueous solution $0.023 \mathrm{M}$ in $\mathrm{KMnO}_{4}$ and $0.09 \mathrm{M}$ in $\mathrm{NaIO}_{4}$. The reaction was allowed to proceed at $37{ }^{\circ} \mathrm{C}$ for $20 \mathrm{~h}$ under stirring. After acidification with $5 \mathrm{~N} \mathrm{H}_{2} \mathrm{SO}_{4}$, the solution was decolorized with a saturated solution of oxalic acid and extracted with diethyl ether $(200 \mathrm{~mL}$, twice). Combined organic phases were dried over $\mathrm{Na}_{2} \mathrm{SO}_{4}$, filtered, and then concentrated in vacuo. The obtained fraction was purified by HPLC (LUNA, SI60, eluent $n$-hexane/EtOAc 65:35) yielding compound 9 (90 $\mathrm{mg}, 0.289 \mathrm{mmol}, 75 \%$ yield) in the pure state.

Compound 9: Amorphous solid. $[\alpha]_{\mathrm{D}}{ }^{25}+80(c=0.10$ in $\mathrm{CHCl}_{3}$ ). ESMS: $\mathrm{m} / \mathrm{z} 303[\mathrm{M}+\mathrm{H}]^{+}, 325[\mathrm{M}+\mathrm{Na}]^{+}$. EIMS: $m / z$ 302 (M). HREIMS: $\mathrm{m} / \mathrm{z}$ 302.1735, calcd for $\mathrm{C}_{15} \mathrm{H}_{26} \mathrm{O}_{6} \mathrm{~m} / \mathrm{z}$ 302.1729. ${ }^{1} \mathrm{H} \mathrm{NMR}\left(\mathrm{CDCl}_{3}\right): \delta 4.50(\mathrm{H}-3, \mathrm{~m}) ; 3.70\left(\mathrm{OCH}_{3}, \mathrm{~s}\right)$; $3.01(\mathrm{H}-2 \mathrm{a}, \mathrm{dd}, J=15.9,10.4 \mathrm{~Hz}) ; 2.50(\mathrm{H}-8, \mathrm{~m}) ; 2.36(\mathrm{H}-2 \mathrm{~b}, \mathrm{dd}$, $J=15.9,2.1 \mathrm{~Hz}) ; 2.19(\mathrm{H}-4, \mathrm{~m}) ; 2.02(\mathrm{H}-7 \mathrm{a}, \mathrm{dd}, J=13.5,9.8$ $\mathrm{Hz}) ; 1.62$ (H-10a, m); 1.54 (H-10b, overlapped); 1.50 (H-7b, overlapped); 1.45 (H-5a, overlapped); $1.37\left(\mathrm{H}_{3}-12, \mathrm{~s}\right) ; 1.34$ (H-5b, overlapped); 1.22 (H-13a, m); 1.14 (H-13b, m); $0.92\left(\mathrm{H}_{3}-11, \mathrm{t}, J\right.$ $=6.6 \mathrm{~Hz}) ; 0.90\left(\mathrm{H}_{3}-14, \mathrm{t}, J=6.6 \mathrm{~Hz}\right) .{ }^{13} \mathrm{C} \mathrm{NMR}\left(\mathrm{CDCl}_{3}\right): \delta$ 181.9 (C-9); 172.2 (C-1); 80.0 (C-6); 78.9 (C-3); $51.9\left(\mathrm{OCH}_{3}\right) ; 42.8$ (C-7); 41.6 (C-8); 34.7 (C-4); 34.4 (C-5); 31.3 (C-2); 27.1 (C-10); 24.9 (C-13); 20.9 (C-12); 11.2 (C-11); 11.0 (C-14).

Methylation of Compound 9. To $40 \mathrm{mg}$ of compound $9(0,132$ mmol) was added dropwise a saturated solution of $\mathrm{CH}_{2} \mathrm{~N}_{2}$ in $\mathrm{Et}_{2} \mathrm{O}$. After removal of the organic solvent, the residue was purified by HPLC (eluant $n$-hexane/EtOAc 95:5, flow $0.8 \mathrm{~mL} / \mathrm{min}$ ) affording pure compound $\mathbf{1 0}(41 \mathrm{mg}, 0.130 \mathrm{mmol})$.

Compound 10: Colorless oil. $[\alpha]_{\mathrm{D}}{ }^{25}+108\left(c=0.10\right.$ in $\left.\mathrm{CHCl}_{3}\right)$. ESMS: $m / z 317[\mathrm{M}+\mathrm{H}]^{+}, 339[\mathrm{M}+\mathrm{Na}]^{+}$. EIMS: $m / z 316(\mathrm{M})$. HREIMS: $m / z$ 316.1895, calcd for $\mathrm{C}_{16} \mathrm{H}_{28} \mathrm{O}_{6} \mathrm{~m} / \mathrm{z}$ 316.1886. ${ }^{1} \mathrm{H}$ NMR $\left(\mathrm{CDCl}_{3}\right): \delta 4.50(\mathrm{H}-3, \mathrm{~m}) ; 3.70\left(\mathrm{OCH}_{3}, \mathrm{~s}\right) ; 3.69\left(\mathrm{OCH}_{3}, \mathrm{~s}\right)$; 3.00 (H-2a, dd, $J=15.9,10.4 \mathrm{~Hz}) ; 2.48(\mathrm{H}-8, \mathrm{~m}) ; 2.36(\mathrm{H}-2 \mathrm{~b}, \mathrm{dd}$, $J=15.9,2.1 \mathrm{~Hz}) ; 2.19(\mathrm{H}-4, \mathrm{~m}) ; 2.02(\mathrm{H}-7 \mathrm{a}, \mathrm{dd}, J=13.5,9.8$ $\mathrm{Hz}) ; 1.60$ (H-10a, m); 1.52 (H-7b, overlapped); 1.48 (H-10b, overlapped); 1.44 (H-5a, overlapped); $1.35\left(\mathrm{H}_{3}-12, \mathrm{~s}\right) ; 1.34$ (H-5b, overlapped); 1.22 (H-13a, m); 1.14 (H-13b, m); $0.90\left(\mathrm{H}_{3}-14, \mathrm{t}, J\right.$ $=6.6 \mathrm{~Hz}) ; 0.88\left(\mathrm{H}_{3}-11, \mathrm{t}, J=6.6 \mathrm{~Hz}\right) .{ }^{13} \mathrm{C} \mathrm{NMR}\left(\mathrm{CDCl}_{3}\right): \delta$ 176.8 (C-9); 172.2 (C-1); 80.1 (C-6); 78.7 (C-3); $51.9\left(\mathrm{OCH}_{3}\right) ; 51.6$ $\left(\mathrm{OCH}_{3}\right) ; 41.9(\mathrm{C}-7) ; 41.6(\mathrm{C}-8) ; 34.7(\mathrm{C}-4) ; 34.3(\mathrm{C}-5) ; 31.3(\mathrm{C}-$ 2); 27.5 (C-10); 25.0 (C-13); 21.0 (C-12); 11.5 (C-11); 11.0 (C14).

Epoxidation of Plakortin. Plakortin (110 $\mathrm{mg}, 0.353 \mathrm{mmol})$ was dissolved in $4 \mathrm{~mL}$ of dry $\mathrm{CH}_{2} \mathrm{Cl}_{2}$, and $84 \mathrm{mg}$ of meta-chloroperbenzoic acid $(0.494 \mathrm{mmol})$ was added to the solution that was then stirred overnight at room temperature. Subsequently, the reaction mixture was partitioned between $\mathrm{CHCl}_{3}$ and saturated aqueous $\mathrm{NaHCO}_{3}$. The organic phase, dried and concentrated in vacuo, was then purified by HPLC (LUNA, SI60, eluent $n$-hexane/EtOAc 9:1) yielding compounds $\mathbf{1 1}$ (41 mg, $0.125 \mathrm{mmol}, 35 \%$ yield) and $\mathbf{1 2}$ (45 mg, $0.137 \mathrm{mmol}, 39 \%$ yield) in the pure state.

Compound 11: Colorless oil. $[\alpha]_{\mathrm{D}}{ }^{25}+63\left(c=0.10\right.$ in $\left.\mathrm{CHCl}_{3}\right)$. ESMS: $m / z, 329[\mathrm{M}+\mathrm{H}]^{+}, 351[\mathrm{M}+\mathrm{Na}]^{+}$. EIMS: $m / z, 328(\mathrm{M})$, 
$312(\mathrm{M}-16)$. HREIMS: $\mathrm{m} / \mathrm{z} 328.2257$, calcd for $\mathrm{C}_{18} \mathrm{H}_{32} \mathrm{O}_{5} \mathrm{~m} / \mathrm{z}$ 328.2250. ${ }^{1} \mathrm{H}$ NMR $\left(\mathrm{CDCl}_{3}\right): \delta 4.51(\mathrm{H}-3, \mathrm{~m}) ; 3.71\left(\mathrm{OCH}_{3}, \mathrm{~s}\right)$; $2.95(\mathrm{H}-2 \mathrm{a}, \mathrm{dd}, J=15.7,10.5 \mathrm{~Hz}) ; 2.73(\mathrm{H}-10, \mathrm{bd}, J=1.7 \mathrm{~Hz})$; 2.52 (H-9, dd, $J=7.0,1.7 \mathrm{~Hz}) ; 2.37$ (H-2b, dd, $J=15.7,3.5 \mathrm{~Hz}$ ); 2.20 (H-4, m); 1.60 (H-7a, overlapped); 1.58 (H-5a, overlapped); 1.56 (H-8, overlapped); $1.55\left(\mathrm{H}_{2}-11\right.$, overlapped); 1.47 (H-7b, overlapped); 1.45 (H-5b, overlapped); $1.38\left(\mathrm{H}_{3}-15, \mathrm{~s}\right) ; 1.36(\mathrm{H}-$ 13a, overlapped); 1.34 (H-16a, overlapped); 1.21 (H-13b, m); 1.15 $(\mathrm{H}-16 \mathrm{~b}, \mathrm{~m}) ; 0.99\left(\mathrm{H}_{3}-12, \mathrm{t}, J=7.8 \mathrm{~Hz}\right) ; 0.94\left(\mathrm{H}_{3}-14, \mathrm{t}, J=7.8\right.$ $\mathrm{Hz}) ; 0.92\left(\mathrm{H}_{3}-17, \mathrm{t}, J=7.8 \mathrm{~Hz}\right) .{ }^{13} \mathrm{C} \mathrm{NMR}\left(\mathrm{CDCl}_{3}\right): \delta 171.9(\mathrm{C}-$ 1); 80.4 (C-6); $78.6(\mathrm{C}-3) ; 62.4(\mathrm{C}-10) ; 59.6(\mathrm{C}-9) ; 51.7\left(\mathrm{OCH}_{3}\right)$; 41.8 (C-7); 36.8 (C-8); 35.3 (C-5); 34.9 (C-4); 31.4 (C-2); 26.2 (C-11); 25.1 (C-13); 25.0 (C-16); 21.5 (C-15); 11.0 (C-17); 10.7 (C-14); 9.9 (C-12).

Compound 12: Colorless oil. $[\alpha]_{\mathrm{D}}{ }^{25}+48\left(c=0.10\right.$ in $\left.\mathrm{CHCl}_{3}\right)$. ESMS: $m / z 329[\mathrm{M}+\mathrm{H}]^{+}, 351[\mathrm{M}+\mathrm{Na}]^{+}$. EIMS: $m / z 328(\mathrm{M})$, $312(\mathrm{M}-16)$. HREIMS: $\mathrm{m} / \mathrm{z} 328.2242$, calcd for $\mathrm{C}_{18} \mathrm{H}_{32} \mathrm{O}_{5} \mathrm{~m} / \mathrm{z}$ 328.2250. ${ }^{1} \mathrm{H} \mathrm{NMR}\left(\mathrm{CDCl}_{3}\right): \delta 4.51(\mathrm{H}-3, \mathrm{~m}) ; 3.71\left(\mathrm{OCH}_{3}, \mathrm{~s}\right)$; $3.02(\mathrm{H}-2 \mathrm{a}, \mathrm{dd}, J=15.7,9.6 \mathrm{~Hz}) ; 2.73(\mathrm{H}-10, \mathrm{dt}, J=5.2,1.7$ $\mathrm{Hz}) ; 2.44$ (H-9, dd, $J=7.8,1.7 \mathrm{~Hz}) ; 2.38(\mathrm{H}-2 \mathrm{~b}, \mathrm{dd}, J=15.7,3.5$ $\mathrm{Hz}) ; 2.18$ (H-4, m); 1.64 (H-7a, dd, $J=14.0,4.4 \mathrm{~Hz}) ; 1.58$ (H-5a, overlapped); 1.57 ( $\mathrm{H}_{2}-11$, overlapped); 1.56 (H-8, overlapped); 1.56 (H-13a, overlapped); 1.47 (H-7b, dd, $J=14.0,4.4 \mathrm{~Hz}) ; 1.45(\mathrm{H}-$ 5b, m); $1.36\left(\mathrm{H}_{3}-15, \mathrm{~s}\right) ; 1.33$ (H-13b, m); 1.20 (H-16a, overlapped); 1.18 (H-16b, overlapped); $1.00\left(\mathrm{H}_{3}-12, \mathrm{t}, J=7.0 \mathrm{~Hz}\right) ; 0.91\left(\mathrm{H}_{3}\right.$ $14, \mathrm{t}, J=7.0 \mathrm{~Hz}) ; 0.90\left(\mathrm{H}_{3}-17, \mathrm{t}, J=7.0 \mathrm{~Hz}\right) .{ }^{13} \mathrm{C} \mathrm{NMR}\left(\mathrm{CDCl}_{3}\right)$ :

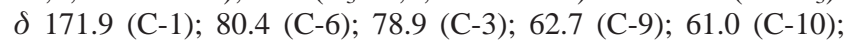
$52.0\left(\mathrm{OCH}_{3}\right) ; 43.7(\mathrm{C}-7) ; 38.2(\mathrm{C}-8) ; 36.3(\mathrm{C}-5) ; 34.8$ (C-4); 31.3 (C-2); 25.2 (C-11); 25.1 (C-13); 24.8 (C-16); 20.2 (C-15); 11.2 (C-17); 11.2 (C-14); 10.2 (C-12).

Reduction of Compound 12. Compound 12 (28 mg, 0.085 mmol) was dissolved in dry diethyl ether, 10 equiv of $\mathrm{LiAlH}_{4}$ was added, and the solution was allowed to stir for $3 \mathrm{~h}$ at room temperature. After completion of the reaction, $\mathrm{H}_{2} \mathrm{O}$ was added and the solution extracted with chloroform. Evaporation in vacuo of the organic phase yielded a mixture that was purified by HPLC (LUNA, SI60, eluent EtOAc) yielding compounds 13 (13 mg, 0.043 mmol, $51 \%$ yield) and 14 (10 mg, $0.033 \mathrm{mmol}, 39 \%$ yield) in the pure state.

Compound 13: Amorphous solid. $[\alpha]_{\mathrm{D}}{ }^{25}+15(c=0.10$ in $\mathrm{CHCl}_{3}$ ). ESMS: $\mathrm{m} / \mathrm{z} 305[\mathrm{M}+\mathrm{H}]^{+}, 327[\mathrm{M}+\mathrm{Na}]^{+}$. EIMS: $\mathrm{m} / \mathrm{z}$ $286(\mathrm{M}-18), 304(\mathrm{M})$. HREIMS: $\mathrm{m} / \mathrm{z}$ 304.2607, calcd for $\mathrm{C}_{17} \mathrm{H}_{36} \mathrm{O}_{4} \mathrm{~m} / \mathrm{z}$ 304.2614. ${ }^{1} \mathrm{H}$ NMR $\left(\mathrm{CDCl}_{3}\right): 4.18(\mathrm{H}-3, \mathrm{~m}) ; 4.16$ $(\mathrm{H}-10, \mathrm{~m}) ; 3.83\left(\mathrm{H}_{2}-1, \mathrm{t}, J=6.0 \mathrm{~Hz}\right) ; 2.19(\mathrm{H}-2 \mathrm{a}, \mathrm{m}) ; 1.97(\mathrm{H}-8$, m); 1.91 (H-4, m); 1.75 (H-9a, overlapped); 1.73 (H-11a, overlapped); 1.68 (H-9b, overlapped); 1.67 (H-5a, dd, $J=13.5,9.8$ $\mathrm{Hz}) ; 1.57$ (H-11b, overlapped); $1.55\left(\mathrm{H}_{2}-7\right.$, overlapped); $1.52(\mathrm{H}-$ 2a, ddd, $J=13.8,6.0,4.3 \mathrm{~Hz}) ; 1.39$ (H-13a, m); 1.36 (H-5b, overlapped); 1.27 (H-16a, m); 1.21 (H-13b, m); $1.19\left(\mathrm{H}_{3}-15, \mathrm{~s}\right)$; $1.13(\mathrm{H}-16 \mathrm{~b}, \mathrm{~m}) ; 0.93\left(\mathrm{H}_{3}-12, \mathrm{t}, J=7.3 \mathrm{~Hz}\right) ; 0.92\left(\mathrm{H}_{3}-17, \mathrm{t}, J=\right.$ $7.3 \mathrm{~Hz}) ; 0.87\left(\mathrm{H}_{3}-14, \mathrm{t}, J=7.3 \mathrm{~Hz}\right)$.

Compound 14: Amorphous solid. $[\alpha]_{\mathrm{D}}{ }^{25}+19(c=0.10$ in $\mathrm{CHCl}_{3}$ ). ESMS: $m / z, 305[\mathrm{M}+\mathrm{H}]^{+}, 327[\mathrm{M}+\mathrm{Na}]^{+}$. EIMS: $m / z$ 286 (M - 18), $304(\mathrm{M})$. HREIMS: $\mathrm{m} / \mathrm{z}$ 304.2627, calcd for $\mathrm{C}_{17} \mathrm{H}_{36} \mathrm{O}_{4} \mathrm{~m} / \mathrm{z}$ 304.2614. ${ }^{1} \mathrm{H}$ NMR $\left(\mathrm{CDCl}_{3}\right): 4.22$ (H-9, m); 4.18 $(\mathrm{H}-3, \mathrm{~m}) ; 3.83\left(\mathrm{H}_{2}-1, \mathrm{t}, J=6.0 \mathrm{~Hz}\right) ; 2.18(\mathrm{H}-2 \mathrm{a}, \mathrm{m}) ; 2.00(\mathrm{H}-8$, $\mathrm{m}) ; 1.92(\mathrm{H}-4, \mathrm{~m}) ; 1.67$ (H-5a, dd, $J=13.5,9.8 \mathrm{~Hz}) ; 1.65(\mathrm{H}-10 \mathrm{a}$, overlapped); 1.62 (H-10b, overlapped); $1.58\left(\mathrm{H}_{2}-7\right.$, overlapped); 1.52 (H-2a, ddd, $J=13.8,6.0,4.3 \mathrm{~Hz}) ; 1.39$ (H-13a, m); 1.36 (H-5b, overlapped); $1.27\left(\mathrm{H}_{2}-11\right.$, overlapped); 1.27 (H-16a, overlapped); 1.21 (H-13b, m); $1.19\left(\mathrm{H}_{3}-15, \mathrm{~s}\right) ; 1.13$ (H-16b, m); 0.92 $\left(\mathrm{H}_{3}-17, \mathrm{t}, J=7.3 \mathrm{~Hz}\right) ; 0.89\left(\mathrm{H}_{3}-12, \mathrm{t}, J=7.3 \mathrm{~Hz}\right) ; 0.88\left(\mathrm{H}_{3}-14\right.$, t, $J=7.3 \mathrm{~Hz}$ ).

Preparation of MTPA Esters of Compound 13. Compound $13(4 \mathrm{mg})$ was dissolved in $1.0 \mathrm{~mL}$ of dry pyridine, treated with (-)-MTPA chloride $(15 \mu \mathrm{L})$ and $N, N$-dimethylaminopyridine (DMAP, a spatula tip), and then maintained at room temperature under stirring overnight. After removal of the solvent, the reaction mixture was purified by HPLC on an SI60 column (eluent $n$-hexane/ EtOAc 95:5), affording (S)-MTPA ester 15 in a pure state $(4.4 \mathrm{mg})$.
Using (+)-MTPA chloride, the same procedure afforded $(R)$-MTPA ester 16 in the same yield.

(S)-MTPA ester (15): Amorphous solid. ESI-MS (glycerol matrix, positive ions): $m / z 975[\mathrm{M}+\mathrm{Na}]^{+} .{ }^{1} \mathrm{H}$ NMR $\left(\mathrm{CDCl}_{3}\right): \delta$ 7.35 and 7.45 (MTPA phenyl protons); 5.73 (H-10, m); 5.63 (H-3, m); $4.29\left(\mathrm{H}_{2}-1, \mathrm{~m}\right) ; 3.59(\mathrm{MTPA} \mathrm{OCH}) ; 2.20(\mathrm{H}-2 \mathrm{a}, \mathrm{m}) ; 2.00(\mathrm{H}-$ $2 \mathrm{~b}, \mathrm{~m}) ; 1.84$ (H-8, overlapped); 1.82 (H-9a, overlapped); $1.75(\mathrm{H}-$ $9 \mathrm{~b}, \mathrm{~m}) ; 1.62\left(\mathrm{H}_{2}-11, \mathrm{~m}\right) ; 1.60$ (H-4, m); 1.18 (H-5a, overlapped); 1.12 (H-16a, overlapped); 1.11 (H-7a, overlapped); $1.05\left(\mathrm{H}_{2}-13\right.$, overlapped); 1.03 (H-7b, overlapped); 0.98 (H-5b, overlapped); 0.95 (H-16b, overlapped); $0.86\left(\mathrm{H}_{3}-15, \mathrm{~s}\right) ; 0.63\left(\mathrm{H}_{3}-12, \mathrm{t}, J=7.3 \mathrm{~Hz}\right)$; $0.62\left(\mathrm{H}_{3}-17, \mathrm{t}, J=7.3 \mathrm{~Hz}\right) ; 0.55\left(\mathrm{H}_{3}-14, \mathrm{t}, J=7.3 \mathrm{~Hz}\right)$.

(R)-MTPA ester (16): Amorphous solid. ESI-MS (glycerol matrix, positive ions): $\mathrm{m} / z 975[\mathrm{M}+\mathrm{Na}]^{+} .{ }^{1} \mathrm{H} \mathrm{NMR}\left(\mathrm{CDCl}_{3}\right): \delta$ 7.32 and 7.55 (MTPA phenyl protons); 5.71 (H-10, m); 5.68 (H-3, m); $4.25\left(\mathrm{H}_{2}-1, \mathrm{~m}\right) ; 3.59$ (MTPA OCH 3$) ; 2.17(\mathrm{H}-2 \mathrm{a}, \mathrm{m}) ; 1.95(\mathrm{H}-$ 2b, m); 1.80 (H-9a, overlapped); 1.76 (H-8, overlapped); $1.73(\mathrm{H}-$ 4, m); 1.70 (H-9b, m); 1.68 (H-11a, m); 1.65 (H-11b, m); 1.36 $(\mathrm{H}-5 \mathrm{a}, \mathrm{dd}, J=14.3,6.7 \mathrm{~Hz}) ; 1.25$ (H-16a, overlapped); $1.21(\mathrm{H}-$ 7a, overlapped); 1.13 (H-7b, overlapped); 1.12 (H-16b, overlapped); $1.12\left(\mathrm{H}_{2}-13\right.$, overlapped); 1.11 (H-5b, overlapped); $1.00\left(\mathrm{H}_{3}-15\right.$, s); $0.73\left(\mathrm{H}_{3}-17, \mathrm{t}, J=7.3 \mathrm{~Hz}\right) ; 0.72\left(\mathrm{H}_{3}-12, \mathrm{t}, J=7.3 \mathrm{~Hz}\right) ; 0.55$ $\left(\mathrm{H}_{3}-14, \mathrm{t}, J=7.3 \mathrm{~Hz}\right)$.

Measurement of in Vitro Antimalarial Activity. Plasmodium falciparum cultures were carried out according to Trager and Jensen's method with slight modifications. ${ }^{13}$ The CQ-sensitive, moderately mefloquine-resistant clone D10 and the CQ-resistant, mefloquine-susceptible clone W2 were maintained at 5\% hemeatocrit (human type A-positive red blood cells) in complete culture medium at $37^{\circ} \mathrm{C}$. Complete medium contained RPMI 1640 medium (Euroclone) with the addition of $10 \%$ heat-inactivated A-positive human plasma, $20 \mathrm{mM}$ HEPES (Euroclone), $2 \mathrm{mM}$ glutamine (Euroclone). All the cultures were maintained in a standard gas mixture consisting of $1 \% \mathrm{O}_{2}, 5 \% \mathrm{CO}_{2}, 94 \% \mathrm{~N}_{2}$. When parasitemia exceeded $5 \%$, subcultures were taken; the culture medium was changed every second day.

Compounds were dissolved in either water (chloroquine) or DMSO (compounds 5-12) and then diluted with medium to achieve the required concentrations (in all cases the final concentration contained $<1 \%$ DMSO, which was found to be nontoxic to the parasite). Drugs were placed in 96-well flat-bottom microplates (Costar \# 3596) and serial dilutions made. Asynchronous cultures with parasitemia of $1-1.5 \%$ and $1 \%$ final hemeatocrit were aliquoted into the plates and incubated for $72 \mathrm{~h}$ at $37{ }^{\circ} \mathrm{C}$. Parasite growth was determined spectrophotometrically $\left(\mathrm{OD}_{650}\right)$ by measuring the activity of the parasite lactate dehydrogenase (LDH), according to a modified version of the method of Makler ${ }^{14,15}$ in control and drug-treated cultures. Antimalarial activity was expressed as the $50 \%$ inhibitory concentrations $\left(\mathrm{IC}_{50}, \mu \mathrm{M}\right)$; each $\mathrm{IC}_{50}$ value presented in Table 1 is the mean and standard deviation of four separate experiments performed in triplicate.

Molecular Modeling. Molecular modeling calculations were performed on SGI Origin 200 8XR12000, while molecular modeling graphics were carried out on SGI Octane 2 and Octane workstations. Plakortin (1) and compounds 2-12, 17, 18 were built using the Insight 2005 Builder module. The estimation of apparent $\mathrm{p} K_{\mathrm{a}}$ values of the newly designed compounds were calculated by using the $\mathrm{ACD} / \mathrm{p} K_{\mathrm{a}} \mathrm{DB}$ version 9.00 software (Advanced Chemistry Development Inc., Toronto, Canada). Compound $\mathbf{9}$ was considered deprotonated while all the others compounds were considered neutral in all calculations performed, as a consequence of the estimation of percentage of neutral/ionized forms computed at the $\mathrm{pH}$ of 7.2 (physiological $\mathrm{pH}$ value) and 5.5 (parasite vacuole $\mathrm{pH}$ ) using the Handerson-Hasselbach equation. The conformational space of all compounds was sampled through 500 cycles of Simulated Annealing (CFF91 force field, ${ }^{16} \epsilon=80 r$ ) by following this protocol: the system was heated up to $1000 \mathrm{~K}$ over $2000 \mathrm{fs}$ (time step $=3.0$ ); the temperature of $1000 \mathrm{~K}$ was applied to the system for 2000 fs (time step $=3.0$ ) with the aim of surmounting torsional barriers; successively temperature was linearly reduced to $300 \mathrm{~K}$ in $1000 \mathrm{fs}$ (time step $=1.0$ ). Resulting structures were 
subjected to energy minimization within Insight 2005 Discover module (CFF91 force field, conjugate gradient algorithm; $\epsilon=80 r$ ) until the maximum rms derivative was less than $0.001 \mathrm{kcal} / \AA$ and subsequently ranked by their conformational energy and torsional angles values. In order to properly analyze the electronic properties, their most stable conformers were subjected to a full geometry optimization by semiempirical calculations, using the quantum mechanical method AM1 in the Mopac 6.0 package $^{17}$ in Ampac/ Mopac module of Insight 2000.1. GNORM value was set to 0.5. To reach a full geometry optimization the criteria for terminating all optimizations was increased by a factor of 100 , using the keyword PRECISE. The lowest energy conformer of Plakortin (1) was superimposed on artemisinin X-ray structure (CSDS code: QNGHSU) by fitting the 1,2-dioxane ring on the 1,2,4-trioxane ring.

Acknowledgment. This work is the result of a research supported by European Community (ANTIMAL project - EU contract LSHP-CT-2005-018834) and by Regione Campania (Italy) (Legge Regionale 5/02, Annualità 2002, "Metaboliti secondari da organismi marini come composti guida per la progettazione razionale di farmaci ad attività antifungina ed antiprotozoaria"). D.T. also acknowledges financial support from the Italian MIUR, PRIN 2003-062554004. Mass and NMR spectra were recorded at the "Centro di Servizio Interdipartimentale di Analisi Strumentale", Università di Napoli "Federico II". The assistance of the staff is acknowledged.

Supporting Information Available: ${ }^{1} \mathrm{H}$ NMR spectra for compounds 5-12, Figure S1, and purity criteria for target compounds. This material is available free of charge via the Internet at http://pubs.acs.org.

\section{References}

(1) Snow, R. W.; Guerra, C. A.; Noor, A. M.; Myint, H. Y.; Hay, S. I. The global distribution of clinical episodes of Plasmodium falciparum malaria. Nature 2005, 434, 214-217.

(2) White, N. J. Antimalarial drug resistance. J. Clin. Invest. 2004, 113, $1084-1092$.

(3) Martensson, A.; Stroemberg, J.; Sisowath, C.; Msellem, M. I.; Gil, J. P.; Montgomery, S. M.; Olliaro, P.; Ali, A. S.; Bjoerkman, A. Efficacy of artesunate plus amodiaquine versus that of artemetherlumefantrine for the treatment of uncomplicated childhood Plasmodium falciparum malaria in Zanzibar, Tanzania. Clin. Infect. Dis. 2005, 41 (8), 1079-1086.

(4) (a) White, N. J. Antimalarial drug resistance and combination chemotherapy. Phil. Trans. R. Soc. Lond. B, 1999, 354, 739-749. (b) South East Asian Quinine Artesunate Malaria Trial (SEAQUAMAT) Group, Lancet 2005, 366, 717. (c) Longo, M.; Zanoncelli, S.; Manera, D.;
Brughera, M.; Colombo, P.; Lansen, J.; Mazué, G.; Gomes, M.; Taylor, W. R. J.; Olliaro, P. Effects of the antimalarial drug dihydroartemisinin (DHA) on rat embryos in vitro. Reprod. Toxicol. 2006, 21, 83-93. (d) Taylor, W. R. J.; White, N. J. Antimalarial drug toxicity: a review. Drug Safety 2004, 27, 25-61.

(5) Ridley, R. G. Medical need, scientific opportunity and the drive for antimalarial drugs. Nature 2002, 415, 686-693.

(6) Cafieri, F.; Fattorusso, E.; Taglialatela-Scafati, O.; Ianaro, A. Metabolites from the sponge Plakortis simplex. Determination of absolute stereochemistry of plakortin. Isolation and stereostructure of three plakortin related compounds. Tetrahedron 1999, 55, 70457056.

(7) Fattorusso, E.; Parapini, S.; Campagnuolo, C.; Basilico, N.; TaglialatelaScafati, O.; Taramelli, D. Activity against Plasmodium falciparum of cycloperoxide compounds obtained from the sponge Plakortis simplex. J. Antimicrob. Chemother. 2002, 50, 883-888.

(8) Campagnuolo, C.; Fattorusso, E.; Romano, A.; Taglialatela-Scafati, O.; Basilico, N.; Parapini, S.; Taramelli, D. Antimalarial polyketide cycloperoxides from the marine sponge Plakortis simplex. Eur. J. Org. Chem. 2005, 5077-5083.

(9) Barluenga, J.; Vazquez-Villa, H.; Ballesteros, A.; Gonzalez, J. M. Copper(II) Tetrafluoroborate Catalyzed Ring-Opening Reaction of Epoxides with Alcohols at Room Temperature. Org. Lett. 2002, 4, 2817-2819.

(10) Ohtani, I.; Kusumi, T., Kashman, Y.; Kakisawa, H. High-field FT NMR application of Mosher's method. The absolute configurations of marine terpenoids. J. Am. Chem. Soc. 1991, 113, 4092-4096.

(11) Hu, J.-F.; Gao, H.-F.; Kelly, M.; Hamann, M. T. Plakortides K.-N, four new cyclic peroxides from an undescribed Jamaican sponge Plakortis sp. (Homosclerophorida, Plakinidae). Tetrahedron 2001, 57, 9379-9383.

(12) (a) Freeman, F.; Lee, C.; Hehre, W. J.; Po, H. N. Ab initio molecular orbital calculations of 3,4-dihydro-1,2-dioxin, 3,6-dihydro-1,2-dioxin, 4H-1,3-dioxin (1,3-diox-4-ene), and 2,3-dihydro-1,4-dioxin (1,4dioxene). J. Comput. Chem. 1997, 18, 1392-1406. (b) Senthilkumar, K.; Kolandaivel, P. Structure, conformation and NMR studies on 1,2 dioxane and halogen substituted 1,2-dioxane molecules. Comput. Biol. Chem. 2003, 27, 173-183.

(13) Trager, W.; Jensen, J. B. Human malaria parasite in continuous culture. Science 1976, 193, 673-675.

(14) Makler, M. T.; Ries, J. M.; Williams, J. A.; Bancroft, J. E.; Piper, R. C.; Gibbins, B. L.; Hinrichs, D. J. Parasite lactate dehydrogenase as an assay for Plasmodium falciparum drug sensitivity. Am. J. Trop. Med. Hyg. 1993, 48, 739-741.

(15) Parapini, S.; Basilico, N.; Mondani, M.; Olliaro, P.; Taramelli, D.; Monti, D. Evidence that haem iron in the malaria parasite is not needed for the antimalarial effects of artemisinin. FEBS Lett. 2004, $575,91-94$.

(16) Maple, J. R.; Hwang, M. J.; Stockfisch, T. P.; Dinur, U; Waldman, M.; Ewig, C. S.; Hagler, A. T.; Derivation of Class II force fields. I. Methodology and quantum force field for the alkyl function group and alkane molecules. J. Comput. Chem. 1994, 15, 162-182.

(17) Stewart, J. J. P. MOPAC: a semiempirical molecular orbital program. J. Comput.-Aided Mol. Des. 1990, 4, 1-105.

JM060899G 